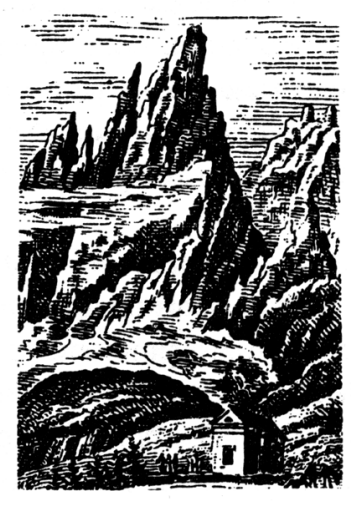

Ewa Grzęda

Uniwersytet Wrocławski

ewa.grzeda@uwr.edu.pl

ewagrzeda@02.pl

\title{
Ponad horyzontem i poza ciałem - 0 dwóch wariantach transgresji w przestrzeni górskiej
}

Słowa-klucze: Góry, granica, transgresja, literatura

Keywords: mountains, border, limitation, transgression, literature

\section{Beyond the horizon and beyond the body - on variants of transgression in the mountains}

\section{Summary}

The article is an attempt to distinguish two main types of transgression usually encountered in the mountains. The first concerns the crossing of geographical and geopolitical borders to be found in the mountains, while the second is associated with the crossing (overcoming) of biological and mental limitations revealed during all kinds of activities in the mountains. The examples referred to in the article have been selected from among literary texts of various genres but thematically linked to the mountains. The author uses primarily fragments of poems, travel accounts from the 
first half of the 19th century as well as several contemporary accounts and pieces of reportage on expeditions to high mountains.

Zanim Antoni Malczewski (utalentowany poeta romantyczny) jako pierwszy Polak i jedenasty Europejczyk stanął w 1818 r. na szczycie Mont Blanc (4810,45 m n.p.m. $)^{1}$, oświeceniowy myśliciel i pisarz, twórca podstaw polskiej geologii Stanisław Staszic wspiął się na Łomnicę (2634 m n.p.m.), jeszcze w XIX w. uważaną za najwyższy szczyt Tatr. Staszic był przekonany, że zdobył szczyt jako pierwszy człowiek w historii. Wrażenia z pobytu na szczycie odnotował następnie w wiekopomnym dziele $O$ ziemiorództwie Karpatów i innych gór i równin Polski, od którego w zasadzie zaczynają się dzieje polskiej literatury o Tatrach ${ }^{2}$. Temu dokonaniu poświęcono wiele uwagi w badaniach nad literaturą o Tatrach, a fragment rejestrujący wrażenia z pobytu na szczycie cytowano wielokrotnie. Zdając sobie z tego sprawę, z pełną świadomością pozwolę go sobie przywołać raz jeszcze w kontekście dyskusji na temat dwóch kategorii (graniczności i transgresyjności) w odniesieniu do przestrzeni górskiej.

Niebo było jasne, a światłość słońca nie olśnęła oczu. Powietrze czyste, dla wzroku łatwiło przezieranie dalekie. Widok niezmierny od północy i od południa; od Bałtyckiego aż do morza Adriatu, słupił swoją wielkością zmysły, razem stawał się miły mojej duszy, gdy mi się w tym samym czasie nasuwała myśl, że te naokoło okiem niezmierzone ziemie są wszystkie siedzibą wielkiego Narodu Słowian, którego ogromna rozległość zastanawiając mnie często, w rozważaniu przyszłego losu narodów, skazywała w stosunkach politycznych niegdyś wielkie jego przeznaczenie, lecz te zdawały się tak jeszcze oddalać, ginąć w nieprzejrzanej czasów przyszłości; właśnie jak tu stąd niezmierne sławiańskie krainy giną w nieprzejrzałej ziem rozstrzeni.

Te na zachód i północ aż ku morzom rozlegające się równiny są moją ojczystą krainą. Po niej rozpościera się najezdników gwałt. Ten mniemając się usprawiedliwiać drugim gwałtem, usiłuje przeistoczyć cny naród i zniszczyć pamięć i imię Polaków ${ }^{3}$.

Staszic, stanąwszy na szczycie Łomnicy (wysoko ponad horyzontem), bynajmniej nie ograniczył się do prostej percepcji przestrzeni literalnej, możliwej do

1 B. Chwaściński, Mont Blanc. Zdobycie szczytu, „Wierchy” 32, 1963, s. 86-118; idem, Narodziny alpinizmu polskiego, „Taternik” 1968, nr 4, s. 153-158. Zob. także J. Kolbuszewski, Kordian na Mont Blanc, [w:] Studia i szkice w dwusetna rocznice urodzin poety, red. E. Grzęda, M. Ursel, Wrocław 2012, s. 5-7.

2 Zob. J. Kolbuszewski, O ziemiorództwie Karpatów... Stanisława Staszica w literaturze romantycznej, [w:] idem, Literatura i Tatry. Studia i szkice, Zakopane 2016, s. 147-171; Z. Libera, Stanisław Staszic - pisarz. Uwagi i spostrzeżenia, [w:] Stanisław Staszic. Materiaty sesji staszicowskiej. Piła 19-20 września 1995, red. J. Olejniczak, Piła 1995, s. 63-73.

3 S. Staszic, O Ziemiorództwie Karpatów i innych gór i równin Polski, Warszawa 1955, s. 186187.

Góry, Literatura, Kultura 11, 2018

(C) for this edition by CNS 
ogarnięcia za pomocą narządu wzroku. W narracji literackiej odnoszącej się do widoku ze szczytu pojawił się krajobraz o wiele szerszy — symboliczny — obejmujący rozległe historyczne ziemie dawnej Słowiańszczyzny i dawnej Polski od Bałtyku po Tatry. Można zaryzykować tezę, że w tym transgranicznym spojrzeniu da się dostrzec element kontrolowanej euforii, tak charakterystyczny dla fizjologii i psychologii w zderzeniu ludzkiego organizmu z przestrzenią górską oraz wysokością i typowymi dla niej parametrami geofizycznymi i atmosferycznymi (dotyczy to m.in. zmniejszającej się ilości tlenu zawartego w atmosferze).

Z punktu widzenia fizykalnej optyki tak szerokie pole widzenia, jakie pojawia się u Staszica, jest oczywistym przekłamaniem. Uzasadnia je natomiast wyobraźnia symboliczna i typowa dla oświeceniowego myśliciela i pisarza wrażliwość geopolityczna oraz wyraźnie ukonstytuowana tożsamość narodowa i społeczna. W rzeczywistości porozbiorowej tak szerokie, „transhoryzontalne” widzenie przestrzeni, symbolicznie przekraczające granice fizyczne i polityczne, wyrasta z nostalgii za utraconym terytorialnym status quo dawnej Rzeczypospolitej. Ma ono zatem charakter perswazyjny i jest formą petryfikacji wyobrażenia o wymiarze przestrzennym dawnej Polski. Staszic, spoglądając ze szczytu Łomnicy, dokonuje tu pierwszej tak spektakularnej transgresji geograficznej, imaginacyjnie przekraczając zasięg wzroku fizycznego. Czynnikiem determinującym tego typu widzenie jest, jak się wydaje, wysokość, fakt przebywania na osi wertykalnej, w szczególnym miejscu, gdzie ziemia wypiętrza się ku niebu, a człowiek niczym prorok ze Starego Testamentu staje na granicy pomiędzy światami.

W wypadku Staszica, pioniersko eksplorującego Tatry na początku XIX w., już sam fakt wkroczenia na terytorium gór dzikich, ciągle jeszcze niezbadanych i nieopisanych, miał wymiar transgresji, która ujawniła się następnie także na poziomie literackiej konkretyzacji spontanicznej gry wyobraźni uruchomionej na szczycie. Ten modelowy sposób szerokiego widzenia z punktu usytuowanego ponad horyzontem opisał i skomentował Jacek Kolbuszewski w rozprawie Znaczenie Stanisława Staszica $w$ dziejach literatury o Tatrach ${ }^{4}$; on też udowodnił istotny wpływ dzieła Staszica na kształtowanie się wrażliwości estetycznej polskich romantyków 5 .

Inwariantem takiego właśnie transgresyjnego widzenia ze szczytu jest jedna $\mathrm{z}$ najsłynniejszych scen $\mathrm{w}$ polskim dramacie romantycznym, rozgrywająca się pod koniec II aktu Kordiana na najwyższej igle Mont Blanc (w rzeczywistości na tym szczycie nie ma igły). Bohater romantycznego dramatu, stojąc na najwyższym szczycie Alp, doświadcza pewnych halucynacji. Widząc unoszący się nad górami zarys postaci szwajcarskiego bohatera narodowego, Arnolda Wienkelrieda, ulega silnym emocjom, co wyraża okrzyk:

4 J. Kolbuszewski, Znaczenie Stanistawa Staszica $w$ dziejach literatury o Tatrach, [w:] Miejsce i znaczenie gór w twórczości Stanisława Staszica. Materiały z sympozjum Kraków, 3 grudnia 2005, red. W.A. Wójcik, Kraków 2005, s. 27-52.

5 J. Kolbuszewski, O ziemiorództwie Karpatów..., s. 147-171. 
Nieście mię chmury! nieście wiatry! nieście, ptacy!

(chmura znosi go z igty lodu)

CHMURA

Siadaj w mgłę — niosęć ... Oto Polska — działaj teraz!...

KORDIAN

(rzucajac się na rodzinna ziemię z wyciagniętemi rękoma, woła)

Polacy!!!

KONIEC AKTU II ${ }^{6}$.

Pomijając szerszy aspekt związany z konwencjonalnym przeżyciem pobytu na szczycie w tradycji romantycznej ${ }^{7}$, pragnę zwrócić uwagę na pewien kontekst tej klasycznej sceny z polskiego dramatu romantycznego - moim zdaniem niezwykle istotny dla zrozumienia zarówno koncepcji zaprezentowanego tu bohatera, jak i wprowadzonej do dramatu przestrzeni bardzo silnie nacechowanej semantycznie. Otóż gdyby zastanowić się nad główną ideą Kordiana, można na podstawie analizy kilku szczegółowych motywów założyć, że jest to dramat o granicach określających kondycję człowieka. Mamy tu bowiem do czynienia z manifestowaniem pewnego rodzaju obsesji zamknięcia i ograniczenia człowieka barierami, nie tylko zewnętrznymi, lecz także biologicznymi (fizjologiczno-anatomicznymi). Dlatego też np. akt I kończy scena nieudanego samobójstwa głównego bohatera, co jest próbą radykalnego wyzwolenia się $\mathrm{z}$ okowów dotychczasowej egzystencji. Poprzedza ją bardzo wymowna wypowiedź Kordiana odpowiadającego na dalekie wołanie kochanki. Kluczowa wydaje się tu symbolika koła wyznaczającego niemożliwe do przekroczenia granice, upośledzające aktywność i wolność romantycznego ,ja”:

\section{KORDIAN}

Ten głos rozwiewa złote zapału świtanie.

Zamknięty jestem w kole czarów tajemniczem,

Nie wyjdę z niego... Mogłem być czemś... Będę niczem... ${ }^{8}$

Drugi raz ta obsesja zamknięcia wyraźnie powraca na szczycie Mont Blanc:

Tu szczyt... lękam się spojrzeć w przepaść świata ciemną.

Spojrzę... Ach! Pod stopami niebo i nad głową

Niebo... Zamknięty jestem w kulę kryształową 9 .

Trzeci raz rozbudowany inwariant tego samego obrazu pojawia się w IV scenie aktu III, już po nieudanej próbie carobójstwa, kiedy najprawdopodobniej dochodzi do swoistego rozdwojenia jaźni Kordiana podczas rozmowy z tajemniczym Dok-

6 J. Słowacki, Kordian, [w:] idem, Dzieła wszystkie, t. 2, red. J. Kleiner, Wrocław 1952, s. 145.

7 Więcej na ten temat zob. artykuł E. Kolbuszewskiej Szczyt górski jako miejsce transgresji. Wersja romantyczna w niniejszym tomie, s. 57-67.

8 J. Słowacki, op. cit., s. 122.

9 Ibidem, s. 143. 
torem. Ten ostatni, kończąc rozmowę o relacjach naród-wieszcz, zwraca się do Kordiana w następujący sposób:

A cóż wiesz, że nie jesteś jak ci obłąkani?

Ty chciałeś zabić widmo, poświęcić się za nic.

O! złota rybko w kryształowej bani,

Tłucz się o twarde brzegi niewidzialnych granic ${ }^{10}$.

Przywołane tu fragmenty wydają się na tyle przezroczyste semantycznie, że nie będziemy ich komentować, w oczywisty sposób eksplikują poczucie „uwięzienia w egzystencji” (termin Marii Janion) i w historii. Końcowa scena aktu II rozgrywająca się na szczycie Mont Blanc — choć może śmieszyć w sferze obrazowej (lot na chmurze) - wydaje się w zarysowanym powyżej kontekście niezwykle ważna, gdyż tak naprawdę jest jedynym momentem manifestacji wolności, zburzenia granic, wyzwolenia z ciała i ograniczeń wynikających z fizycznego rozkładu wektorów sił. Scena na Mont Blanc jest zatem istotna nie tylko $\mathrm{z}$ tego powodu, że na oczach Kordiana dokonuje się narodowa hierofania, której uosobieniem jest fantom Winkelrieda, ale dlatego, że jest to jedyny w całym dramacie moment „,przebicia kryształowej ściany”, uwolnienia głównego bohatera, który metaforycznie przekracza w tej scenie nie tylko granice przestrzenne, lecz także granice ciężaru ciała.

W tym miejscu należy zauważyć, że Słowacki odznaczał się wyjątkową intuicją odnośnie do zjawisk z pogranicza fizjologii i psychologii. Interesowały go biologiczne stany graniczne. Jest przecież autorem powieści poetyckiej Lambro, zawierającej pierwszy w literaturze polskiej opis psychicznych i somatycznych zachowań pod wpływem narkotyku (opium). Biorąc pod uwagę ów biologiczny aspekt sceny pobytu Kordiana na Mont Blanc, łatwiej można zrozumieć euforyczne zachowanie bohatera, wahania nastroju, liczne przeskoki i niekonsekwencje myślowe w słynnym monologu wygłoszonym na najwyższym szczycie Alp.

Zdzisław Jan Ryn w bezprecedensowej w polskich badaniach naukowych monografii Góry, medycyna, antropologia napisał, że zachowania euforyczne w przestrzeni wysokogórskiej są następstwem zmniejszonej ilości tlenu w atmosferze. Obecnie powszechnie wiadomo, że przestrzeń gór wysokich oddziałuje na człowieka nie tylko w aspekcie estetycznym i psychologicznym, lecz także czysto fizjologicznym, wywołując charakterystyczne zespoły zachowań ${ }^{11}$.

Tu warto nadmienić, że pierwsze europejskie opisy choroby wysokościowej pojawiły się już w początkowym okresie rozwoju alpinizmu w rejonie Mont Blanc. Ryn podaje, że autorami pionierskich, amatorskich opisów ostrej choroby wysokościowej byli pierwsi zdobywcy Białej Góry (8 sierpnia 1786 r.) — Jacques Balmat i Michel-Gabriel Paccard ${ }^{12}$. Co ważne, w literaturze polskiej jako pierwszy opis charakterystycznych dla choroby wysokościowej doznań zaobserwowanych w Ta-

10 Ibidem, s. 191.

11 Z.J. Ryn, Góry, medycyna, antropologia, Kraków 2016, s. 24-25.

12 Ibidem, s. 134. 
trach zamieścił Stanisław Staszic w piątym rozdziale cytowanego dzieła $O$ ziemiorództwie Karpatów...:

Przechodząc wysokość 1200 sążni [2160; sążeń nowopolski = 1,728 m] zacząłem czuć pierwszy raz jakąś omdlałość, sił opadłość, czego nigdy nie doświadczałem niżej, chociaż na przykrzejszych jeszcze skałach. Po górach niższych czuć utrudzenie, ale nie wpada się w niemoc i w nagłe sił zniewładnienie. Dopiero około 1200 sążni doświadczyłem tego. Ta niemoc, to opadanie sił bywa takie, iż koniecznie spocząć trzeba, inaczej wszczyna się serca tłuczenie. Kilka minut spoczynku wraca znowu władzę. Nie jest to skutkiem trudności oddechu w rzadszym powietrzu, bo ta rzadkość jest i wtenczas gdy się spoczywa. Ale jest to skutek rozwolnionej sprężystości naszych muskułów, nerwów i żył ${ }^{13}$.

W tym kontekście ciekawa jest podszyta filozofią i frazeologią romantyczną wypowiedź tragicznie zmarłego podczas zimowej wyprawy na Broad Peak, Macieja Berbeki, zacytowana przez Jacka Hugo-Badera w reportażowej książce Długi film o miłości. Powrót na Broad Peak. Jak pisze Bader, nieżyjący himalaista ,jest autorem dziwnych, niezwykłych, poruszających słów o obcowaniu człowieka gór ze śmiercią. Nazwał to spoglądaniem na drugą stronę lustra. Ktoś, kto tego choćby jeden raz w życiu doświadczył, będzie chciał do tego wracać, będzie szukał niebywałych wyzwań, sytuacji, gdzie stawka będzie tak wielka, że znowu uda mu się tam spojrzeć"14. W tej wypowiedzi dotyczącej eksploracyjnej, transgresyjnej postawy w konfrontacji człowieka z przestrzenią gór wysokich (bo chodzi tu o wysokości ekstremalne, generalnie doświadczenie wspinaczki w Himalajach, choć nie tylko) w jakimś stopniu doszukać się można związków z romantycznymi koncepcjami antropologicznymi i romantyczną konwencją literacką. Romantyzm (zwłaszcza w jego odmianie wysokoartystycznej) odwołujący się do spirytualistycznej koncepcji bytu rozdwojonego na ducha i materię interesował się takimi stanami, które można sklasyfikować jako transgresyjne ${ }^{15}$. Przestrzeń górska zdawała się je wywoływać w naturalny sposób. Już samo zderzenie z przestrzenią górską, ekstremalnie wertykalną, wyzwalało w tym pokoleniu kontemplującym dziką przyrodę doświadczenia mistyczne i paramistyczne. Jak się wydaje, również w przypadku Adama Mickiewicza, który tylko pozornie, w nikłym stopniu, czerpał natchnienie artystyczne z wrażeń wywołanych przeżyciem przestrzeni alpejskiej, miała ona istotny wpływ na kształt jego twórczości poetyckiej ${ }^{16}$. W czasie pobytu w Szwajcarii w otoczeniu Alp wysokich stworzył

13 Cyt. za: Z. Ryn, op. cit., s. 163.

14 J. Hugo-Bader, Dlugi film o miłości. Powrót na Broad Peak, Kraków 2014, s. 197.

15 Zob. np. Maski, wyb., oprac. i red. M. Janion, S. Rosiek, Gdańsk 1986; A. Nietresa-Zatoń, Powołani na bunt. Transgresje polskich poetów XIX wieku, Kraków 2010.

${ }^{16}$ E. Grzęda, Między „Ja” poetyckim i krajobrazem, między poezja opisowa i twórczościa mistyczną. Esej o zależnościach pomiędzy percepcja przestrzeni i ewolucją stylu poetyckiego Adama Mickiewicza i Juliusza Słowackiego, [w:] Romantyzm. Literatura - kultura - obyczaj. Prace 
trudny do skomentowania cykl Liryków lozańskich, w których pojawia się cały szereg niepokojących obrazów poetyckich stanowiących manifestację transgresji o charakterze psychofizycznym. Symptomatyczny jest tu znany wiersz $G d y$ tu mój trup, w którym mamy do czynienia z bardzo wyraźnym opisem wyjścia duszy z ciała i symbolicznym przekroczeniem granic przestrzeni fizykalnej ${ }^{17}$.

$\mathrm{Z}$ kolei mówiąc o romantycznym eksperymentowaniu $\mathrm{z}$ cielesnym i doczesnym wymiarem egzystencji, można przywołać także śmiałe próby literackie młodego Zygmunta Krasińskiego opisującego w eseju La Ether doświadczenia z psychoaktywną substancją chemiczną, motywowane chęcią sprawdzenia, jak zachowuje się ciało ludzkie w stanie zbliżonym do śmierci. Mówię o tym nie bez związku z interesującą nas problematyką górską, gdyż w relacjach góry-człowiek pojawiają się podobne przesłanki, a himalaizm sportowy zaliczany jest do sportów ekstremalnych, sytuujących człowieka na niebezpiecznej granicy bycia i niebycia, pochłaniających rokrocznie wiele ofiar ${ }^{18}$.

Hugo-Bader w swojej książce o tej konkretnej, fizycznej granicy przebiegającej na wierzchołkach gór wysokich pisze następująco:

Rejon powyżej 7800 metrów, zwany przez specjalistów strefą śmierci, bo tam może być tylko gorzej, gdzie męczy nawet oddychanie i odpoczywanie, to miejsce, gdzie bez dodatkowego tlenu z butli gwałtowna deterioracja dopada najlepiej nawet zaaklimatyzowanego himalaistę w dwa-trzy dni. Nierzadko pojawiają się omamy wzrokowe i słuchowe, czyli halucynacje, osłabienie krytycyzmu, wspinacze, błądząc na pograniczu świadomości, wpadają w niebezpieczne stany euforii, potem siadają i czekają na śmierć albo gnają na złamanie karku, spadają w przepaść, szczeliny, otchłanie ${ }^{19}$.

W tym obszarze nader często dochodzi do ataków choroby wysokościowej i procesy wyniszczającej organizm deterioracji znacznie i gwałtownie się nasilają, co skutkuje, jak piszą znawcy problemu, ,zacieraniem się granic” pomiędzy organizmem i środowiskiem zewnętrznym oraz zagrożeniem zbliżenia się do stanu fizycznego objawowo podobnego do stanu okołoagonalnego. Hugo-Bader w cytowanej książce pisze na przykład:

mózg na niedotlenienie, na przykład związane z wysokością, reaguje bardzo podobnie jak w stanie NDE. To medyczne pojęcie oznaczające stan bliski śmierci, near death experience, przez który przechodzimy w ostatnich chwilach, dniach, godzinach życia, stan śpiączki, katalepsji,

dedykowane Profesorowi Marianowi Urselowi w 65. rocznicę urodzin, red. M. Jonca, M. Łoboz, Wrocław 2015, s. 26-29.

17 J. Łukasiewicz, Wiersze Adama Mickiewicza, Wrocław 2003, s. 154-162; M. Maciejewski, Mickiewiczowskie czucie wieczności, [w:] idem, Poetyka - gatunek - obraz. W kręgu poezji romantycznej, Wrocław 1977, s. 67-117.

18 Śmierć czeka na Evereście, „Angora” nr 23 (4 VI 2017), s. 73.

19 J. Hugo-Bader, op. cit., s. 266. 
śmierci klinicznej albo wszechogarniającej słabości tuż przed ostatnim westchnięciem. To takie ostatnie westchnięcie ludzkiego mózgu, ostatnia chwila nadzwyczajnego wzrostu aktywności, prawdziwa burza elektryczna przewalająca się przez naszą głowę, podczas której dzieją się rzeczy fascynujące. To są te loty przez tunel, wizje Wielkiego światła, spotkania z dobrem Absolutnym, Bogiem... Opowiadają o tym ludzie, którzy stamtąd wrócilii ${ }^{20}$.

Bardzo przejmująco w tym kontekście brzmi przytoczona przez Hugo-Badera opowieść jednego z najwybitniejszych żyjących polskich alpinistów, Krzysztofa Wielickiego, o swoistym odczuciu obecności „drugiego” przypominającym rozdwojenie jaźni, którego doświadczył podczas zejścia z himalajskiego szczytu Dhaulagiri:

Krzysztofowi Wielickiemu, który wspinał się samotnie na Dhaulagiri i znalazł się w sytuacji bez wyjścia, nie mógł iść wyżej ani schodzić, bo stracił linę, nieznany towarzysz podpowiadał, którędy iść, jak się wycofywać, wybierać drogę. Nie był ani mężczyzną, ani kobietą. Nie był podobny do nikogo znajomego. Wielicki nie miał prawa przeżyć, był niewątpliwie po tamtej stronie lustra i doskonale o tym wie i wiedział. Wiedział, że był sam, ale gawędził z tym Aniołem Stróżem, sam pytał go o drogę.

— Kiedy wykaraskałem się wreszcie jakimś cudem — opowiada — dotarłem do namiotu, rozpaliłem maszynkę i zrobiłem herbatę. I rozlałem ją do dwóch kubków ${ }^{21}$.

W narracji Hugo-Badera opowieść o obecności dziwnego towarzysza lub uzewnętrznionego zdublowanego ,ja” wędrującego obok himalaisty w sytuacji bezpośredniego zagrożenia życia na wysokości klasyfikowanej jako „strefa śmierci” jest wystylizowana na opis sytuacji granicznej. W pewnym sensie może budzić skojarzenia ze słynną sceną rozmowy Kordiana z tajemniczym Doktorem z III aktu Kordiana. Co ciekawe, sam Wielicki w wywiadzie-rzece z Piotrem Drożdżem, wspominając owo przeżycie w zupełnie innej konwencji, stara się swoje dziwne zachowanie zracjonalizować i ukazać w obiektywnym świetle:

Kiedy kilka razy obsunąłem się ze zgrzytem czekanów i raków, wpadłem w panikę. Wydawało mi się, że nie wyjdę z tej opresji. Nie miałem możliwości zjechania, a 1800-metrowe zejście było mało realne. Pozostawała droga w górę.

Gdy tak się miotałem - w lewo, w prawo, w górę i w dół — próbując znaleźć jakąś możliwość wyjścia ze ściany, zacząłem podświadomie konsultować z kimś swoje wybory. Czułem obecność drugiej osoby. Był to

20 Ibidem, s. 111-112.

${ }^{21}$ Ibidem, s. 112-113. 
ktoś - nie miał imienia, nazwiska, nie był kobietą ani mężczyzną. Zwyczajnie — ktoś, kogo chciałem się poradzić, skonsultować mój wybór.

Zjawisko to jest znane z literatury górskiej — pisali o nim inni soliści, na przykład Reinhold Messner, relacjonując wspinaczkę na Nanga Parbat i Jerzy Kukuczka, wspominając solowe wejście na Makalu w 1981 roku. Jak ty interpretujesz to doświadczenie?

Halucynacje, o których pisali Messner i Kukuczka, prawdopodobnie wynikały z niedotlenienia. Ze mną było inaczej: byłem na szczycie wcześniej, więc aklimatyzację miałem świetną. Moje omamy są raczej dowodem na stadność człowieka, który — gdy znajdzie się w pułapce i czuje, że jest to stan zagrożenia życia — szuka pomocy kogoś bliskiego, partnera. Niby od czasu do czasu się na tym łapałem, uświadamiając sobie, że nikogo przy mnie nie ma, ale chwilę później znowu prowadziłem rozmowę. $Z$ jednej strony wkurzało mnie to, bo wydawało mi się, że jest już niedobrze, jeśli tak nieracjonalnie się zachowuję. $Z$ drugiej — bardzo pomagało psychicznie.

W końcu „po odwołaniu się do doświadczenia i szczęścia” — jak pisałeś w ,Taterniku” - udało ci się wyjśćc na grań. Co zadecydowało, że nie poszedłeś na szczyt - wyczerpanie psychiczne czy pogarszające się warunki?

Już w trakcie mojej walki o wyjście ze ściany zaczął padać śnieg. W dodatku na tej szamotaninie straciłem sporo czasu. Kiedy wydostałem się na grań, była godzina piętnasta, dalej padało i było mgliście. Nie było się nad czym zastanawiać, pozostawało tylko schodzenie. Było koszmarne - obsuwałem się na kamieniach pokrytych śniegiem. Znowu zacząłem rozmawiać i radzić się wyimaginowanego towarzysza.

Po trzech godzinach walki doszedłem do trójki, w której zastałem Ingrid i Ralfa, którzy planowali atakować szczyt następnego dnia. Nie było dla mnie miejsca, więc mimo wyczerpania musiałem zejść do biwaku na 7000 metrów, gdzie zastałem dziurawy namiot. Tam podświadomie rozlałem herbatę do dwóch kubków $[\ldots]^{22}$.

We współczesnej literaturze górskiej pojawia się wiele relacji zawierających opisy przeżyć ekstremalnych stanów granicznych o charakterze psychofizycznym. Niektóre z nich sprawiają wrażenie rozmycia odczuwalnych granic powłoki ciała i są doświadczane niejako na zewnątrz organizmu, ,poza ciałem”, co w wielu wypadkach wiąże się z oddziaływaniem na organizm niekorzystnych dla ludz-

22 P. Drożdż, Krzysztof Wielicki. Mój wybór. Wywiad-rzeka, t. 2, Kraków 2015, s. 15-16. 
kiego organizmu atmosferycznych parametrów przestrzeni wysokogórskiej ${ }^{23}$. Co ważne, autopsyjny charakter tych doświadczeń i poszerzający się stan wiedzy z zakresu fizjologii i psychologii wysokogórskiej nie stanowią przeszkody dla pewnego typu konwencjonalizacji, a nawet mitologizacji tych stanów w narracjach literackich. Klasyfikowane jako stany graniczne, okazują się bardzo atrakcyjnym i ważnym motywem w różnego typu relacjach $\mathrm{z}$ wypraw zawodowych himalaistów, są niejako znakiem czy rękojmią najwyższego wtajemniczenia w arkana sztuki wspinaczkowej, dowodem przynależności do elitarnego kręgu zdobywców gór wysokich.

Interesująco na temat tego typu doznań doświadczanych na ekstremalnych wysokościach w szczególnych sytuacjach wyczerpania i zagrożenia życia pisze Adam Bielecki — przedstawiciel najmłodszego pokolenia polskich zawodowych himalaistów - w debiutanckiej książce biograficznej Spod zamarzniętych powiek. Relacjonując powrót z wyprawy na szczyt Makalu, barwnie opowiada o swoich zaburzeniach psychosomatycznych w kontekście utrwalonej tradycji literackiej i badań z zakresu medycyny górskiej:

Pokonaliśmy już najtrudniejszy odcinek. Byliśmy na wysokości $7500 \mathrm{~m}$ n.p.m., na początku trawersu. Pożegnałem się z Tomkiem i poszedłem. Gdy dotarłem do dwójki, wrzuciłem butlę z tlenem, maskę i reduktor do pustego plecaka i zacząłem wracać.

Stało się jednak coś, czego w ogóle nie przewidziałem: nie miałem siły. W dół szło się nieźle, ale z każdym krokiem do góry ciało wrzeszczało coraz głośniej: „Nie pójdziesz! Nie pozwolę ci!”. Tak jakbym miał wbudowany pieprzony żyrokompas i idąc $\mathrm{w}$ górę, zadawał gwałt własnemu organizmowi. Mimo to uparcie szedłem przed siebie. W ciągu godziny przeszedłem może sto metrów.

W pewnym momencie usłyszałem gwizdanie. Rozejrzałem się. Nikogo nie było. Idę dalej. Ktoś tam siedzi? Nie, przecież to kamień. A co to za dźwięk? Znowu to gwizdanie. Momentami obraz drżał mi jak w zepsutym telewizorze. Myślałem trzeźwo, ale uczucie było takie, jakby ktoś siedział mi w głowie i robił sobie żarty. Wydawało mi się, że ktoś mnie obserwuje. Niedobrze, pomyślałem, mam omamy. Jeszcze niezbyt mocne, ale co będzie za chwilę? Znów to gwizdanie. Próbowałem je zignorować. Ciarki przeszły mnie pół godziny potem, kiedy ktoś zagwizdał i odezwał się do mnie głosem małej dziewczynki:

Zamarzniesz.

Usiadłem na śniegu ${ }^{24}$.

${ }^{23}$ Zob. A Matuszyk, Humanistyczne podstawy teorii sportów przestrzeni (na przykładzie alpinizmu), Kraków 1998, s. 79-83.

${ }^{24}$ A. Bielecki, D. Szczepański, Spod zamarzniętych powiek, Warszawa 2017, s. 172-173. 
Bielecki ciekawie opowiada o granicy pomiędzy kontrolą i jej utratą nad własnym ciałem, psychiką i percepcją. Opowieść ta pojawia się w kontekście wejścia przypieczętowującego wkroczenie autora do kręgu doświadczonych himalaistów, jest zatem potwierdzeniem pewnego typu inicjacji. W jego przypadku osiągnięcie wysokości 7500 m. n.p.m. przy oddziaływaniu dodatkowych czynników (zmęczenie, określony zasób doświadczeń) stanowiło granicę wystąpienia typowych zaburzeń sensorycznych. Zetknięcie się z nimi po raz pierwszy w rozpoczynającej się karierze himalaisty miało szczególnego rodzaju walory poznawcze. Bielecki, komentując w relacji książkowej indywidualne przeżycie graniczne, świadomie je obiektywizuje, powołując się na najnowsze osiągnięcia badawcze:

W swojej książce Góry - Medycyna - Antropologia profesor psychiatrii Zdzisław Jan Ryn pisze o zaburzeniach psychicznych towarzyszących pobytowi na dużych wysokościach: „W każdej sytuacji ekstremalnej człowiek sięga do granic możliwości i często te granice przekracza. Kiedy wysiłek przekracza naturalną wydolność i odporność organizmu, wówczas pojawiają się problemy patologii, choroby, jako ostatecznej próby obrony przed zagrożeniem". W literaturze górskiej często pojawia się motyw halucynacji, najczęściej są to omamy słuchowe lub wzrokowe. Na przykład Barry Bishop, jeden z członków amerykańskiej wyprawy na Mount Everest z 1963 roku, powyżej 8000 m n.p.m. odczuwał klaustrofobiczny lęk, nie rozpoznawał swojego partnera, czuł, że jest aniołem, i wsłuchiwał się w odgłosy wiatru, które układały się w różne słowa lub przypominały dźwięk dzwonu. Charakterystyczne dla himalaistów jest doświadczenie obecności innej — nieistniejącej — osoby. We wspomnianej już książce Ryn zebrał wiele takich historii, będących udziałem również polskich himalaistów. Podczas wspinaczki na Dhaulagiri Krzysztofa Wielickiego zaskoczyła obecność wyimaginowanego przyjaciela, osoby, której rozpaczliwie potrzebował. Rozmawiał z tą osobą, a nawet rozlał herbatę do dwóch kubków — wtedy uświadomił sobie, że jest sam. Jurek Kukuczka również gotował dla dwóch osób podczas samotnej wspinaczki na Makalu (,mam takie silne poczucie czyjejś obecności, że przyłapuję się na przemożnej chęci rozmawiania z nim"). Niejednokrotnie ta wyimaginowana postać ratuje życie. Tak było w przypadku Rogera Marshalla. Greg Child w jednej z moich ulubionych książek górskich pod tytułem Mieszane uczucia opisuje sytuację, którą przeżył ten brytyjsko-kanadyjski wspinacz po samotnym wejściu na Kanczendzongę. Schodząc, Roger zgubił drogę, gdy nagle usłyszał głos mówiący coś po japońsku. Idąc w jego kierunku, trafił na starą linę poręczową zostawioną w tym miejscu przez uczestników japońskiej wyprawy. Himalaiści na dużych wysokościach widzieli rosyjskie czołgi, byli przekonani, że biorą udział w wojnach, odgłosy liny ocierającej się o śnieg przypominały im znane piosenki. Polski wspinacz, który wszedł 
na Pik Korżeniewskiej (7105 m n.p.m.), widział budkę z lodami i nieznanego sprzedawcę, a potem z buta jego kolegi wyleciała na miotle czarownica. Wspinacz przeczekał, aż wiedźma odleci, i poszedł w kierunku wierzchołka [Przytoczone historie omamów towarzyszących pobytowi na dużych wysokościach oraz komentujące je cytaty pochodzą z książki Zdzisława Jana Ryna Góry - Medycyna - Antropologia, Medycyna Praktyczna 2015.

W tym kontekście moja halucynacja złożona z powtarzającego się gwizdania i jednego wypowiedzianego słowa zdaje się dość uboga, niemniej sądzę, że uratowała mi życie. Gdybym tępo szedł do góry, to prawdopodobnie nie przeżyłbym kolejnej nocy ${ }^{25}$.

Bielecki nie ukrywa, że góry wysokie są dla niego obszarem różnego typu eksploracji, nie tylko zewnętrznych ale i wewnętrznych, dlatego świadomie mówi o nich w kategoriach przestrzeni o wyjątkowych właściwościach, oddziałującej nie tylko na zmysły, lecz także na podświadomość, generującej stany i doświadczenia klasyfikowane jako mistyczne czy paramistyczne:

Kopuła szczytowa Chan Tengri jest zbudowana z marmuru. W promieniach zachodzącego słońca wydawała się płonąć krwistą czerwienią. Chmury mieniły się fioletami i seledynami. Aż trudno uwierzyć, że natura potrafi stworzyć taką paletę barw.

Nie mam wątpliwości, że gdyby zawieziono mnie tam helikopterem, to również doceniłbym ten widok, ale nie byłoby to doświadczenie mistyczne. Potrzebowałem dwudziestu godzin w kuckach w rozwalonym namiocie, aby poczuć szczęście i jedność z otaczającymi mnie górami. Z czasem nauczyłem się osiągać ten stan szybciej i łatwiej. Takich momentów szukam w górach.

Żeby to zrozumieć, trzeba by się zgłębić w zjawisko deprywacji sensorycznej. W dużych miastach można pójść do specjalnej komory. Kładziesz się w słonej wodzie, która cię unosi, nie ma tam dostępu światła, dźwięku, nie ma bodźców. To prowadzi do głębokich stanów mistycznych porównywalnych z działaniem środków psychodelicznych. Mogą wystąpić halucynacje. Te stany odnajduję w himalaizmie. W cierpieniu można znaleźć coś fascynującego. Pustelnicy, mistycy, ludzie uważani za odmieńców właśnie tego szukali w samotności. Chcesz poznać naturę człowieka? Przegłódź go, zmęcz, wychłódź, nie daj mu się wyspać. Wtedy zrzuci maskę, bo nie będzie miał siły jej nosić. Jeśli chcesz zobaczyć, do czego zdolny jest twój przyjaciel, zabierz go na wyprawę. Mamy wyobrażenia na swój temat. Himalaizm weryfikuje je bezlitośnie. To samo robią wojna czy samotny rejs. Jednym z piękniejszych aspektów wspinania jest to, że w pewnym momencie w moim umyśle nie ma nic

25 Ibidem, s. 173-175. 
poza kilkoma metrami kwadratowymi skały, świadomością własnego ciała i analizą warunków. Podczas ataku szczytowego jestem poza lękiem, polityką, tym, co się dzieje na dole. To stan głębokiej koncentracji, bardzo oczyszczający. Góry są moją świecką formą duchowości. Stany medytacyjne - odwodnienie, wychłodzenie, głód — mogą być źródłem samorozwoju ${ }^{26}$.

W narracji Bieleckiego i innych relacjach wybitnych himalaistów nader interesujące wydają się pewne konwergencje pomiędzy romantycznym sposobem widzenia i rozumienia reakcji ludzkiego organizmu na nieokiełznaną, dziką przestrzeń górską a obserwacjami i doznaniami współczesnych himalaistów. To właśnie na progu romantyzmu rozpoczyna się proces zdobywania gór wysokich przez człowieka, choć ośmiotysięczniki pozostają jeszcze wówczas poza sferą ludzkiego doświadczenia. Od tamtej pory człowiek zaczyna wdzierać się na najwyższe wierzchołki rozmaitych pasm górskich w trybie sportowym, walcząc ze słabościami fizycznymi i dążąc do przekraczania i poszerzania granic wydolności organizmu. Popularność wspinaczki wysokogórskiej wzrasta z czasem bez względu na ilość ofiar śmiertelnych.

Do pewnego stopnia skonwencjonalizowane, ale jednak oparte na dominującym przeżyciu autopsyjnym dawne i współczesne relacje z wypraw wysokogórskich zdają się potwierdzać, że przypisywana górom (ze względu na ich naturalne usytuowanie w przestrzeni i naturalną strukturę wertykalną) funkcja granicy jest archetypiczna i w związku z tym w naturalny sposób prowokuje do podejmowania kolejnych prób świadomego jej przekraczania bez względu na konsekwencje.

26 Ibidem, s. 58-59. 